\title{
CHARACTERISTIC OF AIRBORNE PARTICULATE MATTER SAMPLES COLLECTED FROM TWO SEMI INDUSTRIAL SITES IN BANDUNG, INDONESIA
}

\author{
Diah Dwiana Lestiani ${ }^{1, *}$, Muhayatun Santoso ${ }^{1}$, Syukria Kurniawati ${ }^{1}$, and Andreas Markwitz ${ }^{2}$ \\ ${ }^{1}$ National Nuclear Energy Agency of Indonesia, BATAN, \\ Nuclear Technology Center for Materials and Radiometry, Jl. Tamansari 71, Bandung 40132, Indonesia \\ ${ }^{2}$ Institute of Geological Nuclear Sciences (GNS), Lower Hutt, New Zealand
}

Received October 9, 2013; Accepted November 14, 2013

\begin{abstract}
Air particulate matter concentrations, black carbon as well as elemental concentrations in two semi industrial sites were investigated as a preliminary study for evaluation of air quality in these areas. Sampling of airborne particulate matter was conducted in July 2009 using a Gent stacked filter unit sampler and a total of 18 pairs of samples were collected. Black carbon was determined by reflectance measurement and elemental analysis was performed using particle induced X-ray emission (PIXE). Elements $\mathrm{Na}, \mathrm{Mg}, \mathrm{Al}, \mathrm{Si}, \mathrm{P}, \mathrm{S}, \mathrm{Cl}, \mathrm{K}, \mathrm{Ca}, \mathrm{Ti}, \mathrm{Cr}, \mathrm{Mn}, \mathrm{Fe}, \mathrm{Cu}$, $\mathrm{Zn}$ and As were detected. Twenty four hour $P M_{2.5}$ concentration at semi industrial sites Kiaracondong and Holis ranged from 4.0 to $22.2 \mu \mathrm{g} \mathrm{m}^{-3}$, while the $P M_{10}$ concentration ranged from 24.5 to $77.1 \mu \mathrm{g} \mathrm{m}^{-3}$. High concentration of crustal elements, sulphur and zinc were identified in fine and coarse fractions for both sites. The fine fraction data from both sites were analyzed using a multivariate principal component analysis and for Kiaracondong site, identified factors are attributed to sea-salt with soil dust, vehicular emissions and biomass burning, non ferrous smelter, and iron/steel work industry, while for Holis site identified factors are attributed to soil dust, industrial emissions, vehicular emissions with biomass burning, and sea-salt. Although particulate samples were collected from semi industrial sites, vehicular emissions constituted with $S, Z n$ and BC were identified in both sites.
\end{abstract}

Keywords: airborne particulate matter; semi industrial sites; principal component analysis; PIXE

\section{ABSTRAK}

Investigasi terkait konsentrasi massa partikulat udara, black carbon dan konsentrasi unsur pada sampel partikulat udara yang disampling di dua daerah semi industri merupakan studi pendahuluan sebagai evaluasi kualitas udara di daerah ini. Sampling sampel partikulat udara dilakukan di bulan Juli 2009 menggunakan sampler Gent stacked filter unit, dan diperoleh sebanyak 18 pasang sampel. Penentuan Black carbon dilakukan menggunakan pengukuran reflektansi dan analisis unsur dilakukan menggunakan particle induced x-ray emission (PIXE). Unsur-unsur Na, Mg, Al, Si, P, S, Cl, K, Ca, Ti, Cr, Mn, Fe, Cu, Zn dan As dapat dideteksi dengan baik. Konsentrasi 24 jam $P_{2.5}$ di daerah semi industri Kiaracondong dan Holis berkisar 4,0 hingga 22,2 $\mu \mathrm{g} \mathrm{m}^{-3}$, sementara konsentrasi $P M_{10}$ berkisar 24,5 hingga $77,1 \mathrm{\mu g} \mathrm{m}^{-3}$. Unsur-unsur tanah, sulfur dan seng terdeteksi dalam konsentrasi tinggi pada sampel partikulat udara halus maupun kasar pada kedua lokasi. Data partikulat halus dari kedua lokasi selanjutnya diolah menggunakan multivariate principal component analysis, untuk daerah Kiaracondong dapat diidentifikasikan faktor yang berasal dari garam laut dan debu tanah, emisi kendaraan bermotor dan pembakaran biomassa, peleburan logam non besi, industri besi/baja, sementara itu untuk daerah Holis teridentifikasi faktor yang berasal dari debu tanah, emisi industri, emisi kendaraan bermotor dengan pembakaran biomassa dan garam laut. Sekalipun sampel partikulat udara diambil di lokasi semi industri, sumber pencemaran berupa emisi kendaraan bermotor yang terkait korelasi S, Zn dan BC teridentifikasi pada kedua lokasi.

Kata Kunci: sampel partikulat udara; lokasi semi industri; principal component analysis; PIXE

\section{INTRODUCTION}

Air pollution has become an important problem that requires serious attention due to its impact on human health and environmental quality. A large number of epidemiological studies have shown that air pollution causes adverse human health effects [1-2]. Studies of air pollution in Indonesia are, however, very limited and regulatory decisions must be made based on pollution models from other countries [3-4]. There is a need to establish baseline air pollution data across the country, to identify the major sources of air pollution, and to

* Corresponding author. Tel/Fax : +62-22-250-3997/4081

Email address : diahdwi@batan.go.id

Diah Dwiana Lestiani et al. 




Fig 1. Sampling sites of semi industrial area Kiaracondong and Holis, Bandung

investigate the spatial and temporal patterns of transport and deposition of particular air pollutants to the Indonesian environment. Some publications related to air pollution level in urban Bandung and suburban Lembang have been published. Santoso et al. [5] reported on the composition and source apportionment of fine and coarse particle samples collected in Bandung and Lembang, Indonesia between 2002 and 2004. The mean values of $\mathrm{PM}_{2.5}$ concentrations in Bandung and Lembang were $14.03 \pm 6.86$ and $11.88 \pm 6.60 \mu \mathrm{g} \mathrm{m} \mathrm{m}^{-3}$, respectively. The mean values of $\mathrm{PM}_{10-2.5}$ concentrations in Bandung and Lembang were 17.64 \pm 9.42 and $7.10 \pm 7.04 \mathrm{~m} \mathrm{~m} \mathrm{~m}^{-3}$, respectively. Only limited publications of air pollution in Indonesia are available, and the data of air quality in industrial area are still limited. Industrial emissions are believed to be one of major contributor to particulate matter, therefore this study will assess the $\mathrm{PM}_{2.5}$ and $\mathrm{PM}_{10}$ level in industrial areas particularly in Bandung. Besides that, the objective of this research is also as a pre-study to identify the sources that could contribute to the particulate mass especially from industrial emissions in the areas.

Bandung is the capital city of West Java Province and the third largest city in Indonesia, located at 768 meters above sea level, approximately $140 \mathrm{~km}$ southeast of Jakarta. The city is surrounded by volcanoes. This topography characteristic making Bandung has lower temperatures year-around than most other Indonesian cities and can be classified as humid with the average temperature is $23.6^{\circ} \mathrm{C}$ throughout the year. In general, Bandung has two seasons, dry season (April to September) and wet season (October to March). Bandung has estimated population of 2.39 million based on population census 2010 [6]. Many small scale factories are located in and around the city. Commercial activities are mostly concentrated in the center, while industrial activities are concentrated in the west and east side of the city. There are several pockets of slum areas, where housing conditions are poor, waste disposal systems are lacking, green space is negligible, and in addition industry and residential development occur together. The rapid growth of industry, population and motor vehicle usage has strongly affected the city's environmental quality. The disparity in number of motor vehicles and available road has created a traffic jam problem almost in every section of the city, and has caused the air quality deterioration. Pollution sources that have significant effects on the city are secondary sulfate, soil dust, road dust, motor vehicles, biomass burning and industry $[5,7]$. The sampling sites Kiaracondong and Holis areas are not only surrounded by many small scale industries but also mixed with residential, school and commercial activities. Kiaracondong is located in the east of the city, and there is one big scale industry in that area. Holis is located in the western part of the city, and there 
Table 1. The sampling data, mean mass and $B C$ concentrations $\left(\mu \mathrm{g} \mathrm{m}^{-3}\right)$

\begin{tabular}{lccccccc}
\hline \multirow{2}{*}{ Sampling site } & \multirow{2}{*}{$\mathrm{n}$} & \multicolumn{2}{c}{$\mathrm{PM}_{2.5}$} & \multicolumn{2}{c}{$\mathrm{PM}_{10}$} & \multicolumn{2}{c}{$\mathrm{BC}$} \\
\cline { 2 - 7 } & & Range & Mean & Range & Mean & Range & Mean \\
\hline Kiaracondong & 10 & $4.0-22.2$ & 15.9 & $34.1-56.8$ & 43.4 & $0.8-3.7$ & 2.6 \\
Holis & 8 & $4.1-20.5$ & 13.9 & $24.5-77.1$ & 48.3 & $0.8-3.6$ & 2.7 \\
\hline
\end{tabular}

are many small and big scale industries dominated by textile and paper industries.

\section{EXPERIMENTAL SECTION}

\section{Samplings}

Samplings were carried out in semi industrial areas, Kiaracondong and Holis street in Bandung. The location of sampling sites is shown in Fig. 1. The distance between these locations is $6 \mathrm{~km}$ away.

Samples were collected from 6 to 31 July 2009 using a Gent stacked filter unit sampler provided by International Atomic Energy Agency that capable for collecting particulate matter in the $\mathrm{PM}_{2.5-10}$ (coarse) fraction and $\mathrm{PM}_{2.5}$ size (fine) fraction [8]. The coarse fraction $\mathrm{PM}_{2.5-10}$ samples were collected on an $8.0 \mu \mathrm{m}$ nuclepore filters, whereas the fine fraction $\mathrm{PM}_{2.5}$ samples were collected on $0.4 \mu \mathrm{m}$ nuclepore filters. Sampling was performed at a flow rate of 15-18 L. min $^{-1}$ for $24 \mathrm{~h}$ with a frequency of twice to three times per week over 3 to 4 week periods. Sampler was placed on the rooftop of a building $5 \mathrm{~m}$ above ground level and the intake nozzle of the sampler is located $1.8 \mathrm{~m}$ above the roof. The total of 18 pairs of $\mathrm{PM}_{2.5}$ and $\mathrm{PM}_{2.5-10}$ samples were collected from both areas.

\section{Mass Concentration, Black Carbon and Elemental Analysis}

The particulate matter mass of each fine and coarse fractions were determined by gravimetric using a six digits microbalance. The filters were stored for $24 \mathrm{~h}$ prior to weighing in controlled environmental condition room. Mass concentrations of $\mathrm{PM}_{2.5}$ and $\mathrm{PM}_{2.5-10}\left(\mu \mathrm{g} \mathrm{m}^{-3}\right)$ were obtained by dividing the gravimetric mass by the volume of air that passed through the filter. The concentration of black carbon (BC) in the samples was determined by reflectance measurement using an EEL Smoke Stain Reflectometer model 43D. Secondary standard of known reflectance were used to calibrate the reflectometer. Elemental analysis was performed using particle induced $x$-ray emission at the Institute of Geological and Nuclear Sciences (GNS), New Zealand. The X-ray spectra were analyzed using the computer code GUPIX [9] and calibration of the PIXE system was performed by irradiating suitable Micromatter thin target standards [10].

\section{Factor Analysis}

Most factor analysis has been based on an eigenvector analysis. The simplest form of factor analysis is principal component analysis (PCA). This method attempts to simplify the description of a system by determining a minimum set of basis vectors that span the data space to be interpreted. Since PCA can only be performed $\mathrm{n}$ a set of samples in which the various sources contribute different amount of particles to each samples, the mass balance needs to be expanded to a matrix equation:

$$
Z=A \cdot F
$$

where, $Z$ is a matrix of sample vectors, $A$ is the matrix of loading vectors related to the source compositions and $F$ is the matrix of scores that are related to the contribution of that source type to the variance of that particular measured variable. PCA has been widely used in studies of airborne particulate matter composition data [11].

\section{RESULT AND DISCUSSION}

\section{Particulate Matter and Black Carbon Concentrations}

$\mathrm{PM}_{2.5}, \mathrm{PM}_{10}$ and $\mathrm{BC}$ concentrations for each site are summarized in Table 1 . Twenty four hour $\mathrm{PM}_{2.5}$ concentration at semi industrial sites Kiaracondong and Holis ranged from 4.0 to $22.2 \mu \mathrm{g} \mathrm{m}^{-3}$, while the $\mathrm{PM}_{10}$ concentration ranged from 24.5 to $77.1 \mu \mathrm{g} \mathrm{m}^{-3}$. $\mathrm{PM}_{2.5}$ and $\mathrm{PM}_{10}$ concentrations for both sites are shown in Fig. 2. The mean $\mathrm{PM}_{2.5}$ concentrations for Kiaracondong and Holis sites were 15.9 and $13.9 \mu \mathrm{g}$ $\mathrm{m}^{-3}$, respectively, while the mean $\mathrm{PM}_{10}$ concentrations were 43.4 and $48.3 \mathrm{\mu g} \mathrm{m}^{-3}$, respectively. Assuming that these 4 weeks of sampling can represent the annual mean of $\mathrm{PM}_{2.5}$ level, most of the $\mathrm{PM}_{2.5}$ concentrations in sampling site Kiaracondong would exceed the Indonesian national ambient air quality standard of an annual mean $\mathrm{PM}_{2.5}$ value of $15 \mu \mathrm{g} \mathrm{m}^{-3}$ [12]. However, none of $\mathrm{PM}_{2.5}$ and $\mathrm{PM}_{10}$ concentrations in each sampling sites exceeded the twenty four hour Indonesian NAAQS for $\mathrm{PM}_{2.5}$ and $\mathrm{PM}_{10}$ (65 and $150 \mu \mathrm{g}$ $\mathrm{m}^{-3}$, respectively).

The mean of $\mathrm{BC}$ concentrations in Kiaracondong and Holis were 2.6 and $2.7 \mu \mathrm{g} \mathrm{m}^{-3}$, respectively. The average ratio of $\mathrm{BC}$ to $\mathrm{PM}_{2.5}$ concentrations at these 


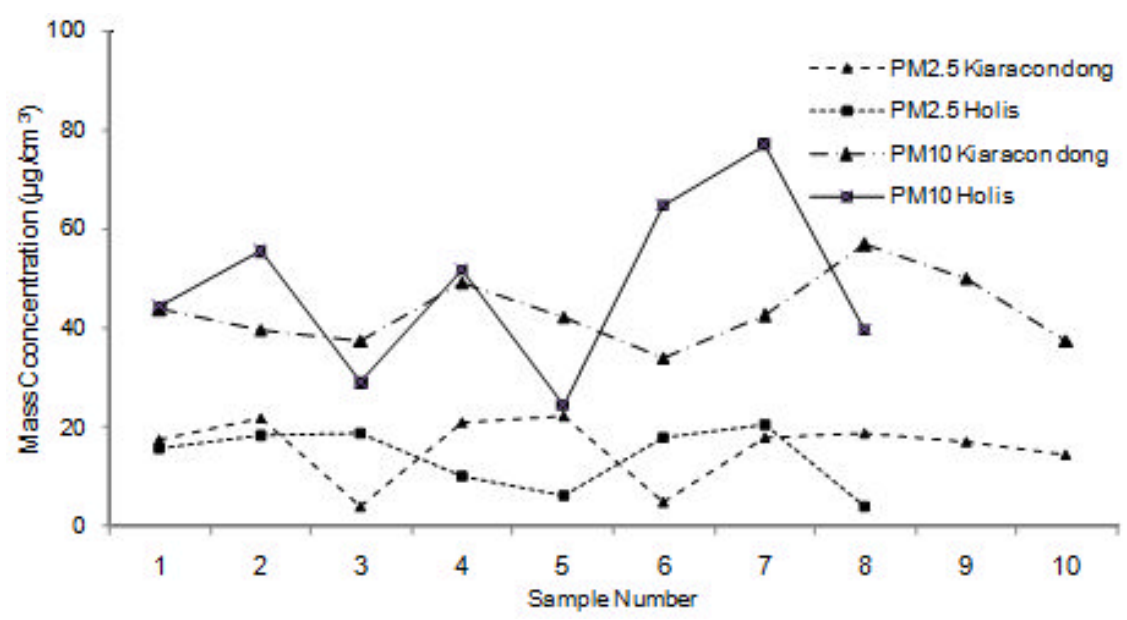

Fig 2. PM mass concentrations at the two semi industrial sampling sites in July 2009

Table 2. Elemental concentrations $\left(\mu \mathrm{g} \mathrm{m}^{-3}\right)$ in fine and coarse fractions collected in July 2009 , a. in Kiaracondong sampling site

\begin{tabular}{crrrrrrrr}
\hline \multirow{2}{*}{ Element } & \multicolumn{3}{c}{ Fine-Kiaracondong } & \multicolumn{3}{c}{ Coarse-Kiaracondong } \\
\cline { 2 - 8 } & Mean & \multicolumn{1}{c}{ Stdev } & Min & Max & Mean & Stdev & Min & Max \\
\hline $\mathrm{Na}$ & 131.88 & 88.89 & 45.14 & 286.01 & 677.38 & 153.13 & 396.09 & 913.30 \\
$\mathrm{Mg}$ & 51.65 & 15.73 & 26.02 & 76.18 & 251.73 & 54.70 & 148.98 & 324.62 \\
$\mathrm{Al}$ & 72.56 & 27.77 & 28.13 & 114.90 & 843.14 & 166.31 & 555.65 & 1135.42 \\
$\mathrm{Si}$ & 129.25 & 46.81 & 54.72 & 191.06 & 1607.43 & 342.36 & 1074.77 & 2166.32 \\
$\mathrm{P}$ & 19.58 & 8.74 & 4.79 & 30.04 & 109.52 & 19.24 & 77.48 & 148.20 \\
$\mathrm{~S}$ & 669.32 & 298.92 & 135.50 & 1124.21 & 505.95 & 100.24 & 347.89 & 689.37 \\
$\mathrm{Cl}$ & 38.58 & 18.03 & 19.52 & 88.71 & 549.67 & 287.26 & 158.20 & 1024.69 \\
$\mathrm{~K}$ & 149.80 & 59.10 & 38.20 & 209.50 & 176.54 & 38.02 & 125.82 & 243.53 \\
$\mathrm{Ca}$ & 44.30 & 18.83 & 14.69 & 79.23 & 743.03 & 153.35 & 512.18 & 1095.26 \\
$\mathrm{Ti}$ & 3.73 & 2.49 & 0.78 & 7.37 & 50.34 & 16.65 & 30.06 & 90.88 \\
$\mathrm{Cr}$ & 1.21 & 1.07 & 0.24 & 3.74 & 3.72 & 2.00 & 1.00 & 6.17 \\
$\mathrm{Mn}$ & 1.75 & 1.90 & 0.14 & 6.42 & 14.33 & 5.09 & 10.03 & 26.93 \\
$\mathrm{Fe}$ & 54.32 & 24.36 & 17.04 & 91.05 & 657.66 & 133.60 & 426.69 & 932.98 \\
$\mathrm{Cu}$ & 1.65 & 0.72 & 0.44 & 2.93 & 5.28 & 4.53 & 1.00 & 13.30 \\
$\mathrm{Zn}$ & 20.31 & 11.57 & 8.40 & 40.35 & 28.07 & 10.77 & 11.12 & 39.74 \\
$\mathrm{As}$ & 3.56 & 2.56 & 1.12 & 7.47 & 7.87 & 5.52 & 2.15 & 18.17 \\
\hline
\end{tabular}

b. in Holis Sampling Site

\begin{tabular}{crrrrrrrr}
\hline \multirow{2}{*}{ Element } & \multicolumn{4}{c}{ Fine-Holis } & \multicolumn{4}{c}{ Coarse-Holis } \\
\cline { 2 - 9 } & Mean & \multicolumn{1}{c}{ Stdev } & Min & Max & Mean & Stdev & Min & Max \\
\hline $\mathrm{Na}$ & 98.13 & 54.50 & 25.65 & 182.76 & 605.13 & 161.43 & 368.75 & 842.46 \\
$\mathrm{Mg}$ & 55.60 & 21.24 & 29.36 & 93.68 & 263.07 & 100.81 & 35.89 & 430.52 \\
$\mathrm{Al}$ & 110.15 & 81.89 & 18.57 & 317.29 & 1164.21 & 489.60 & 23.47 & 1878.29 \\
$\mathrm{Si}$ & 216.76 & 173.02 & 35.41 & 674.81 & 2410.60 & 975.83 & 51.96 & 3920.32 \\
$\mathrm{P}$ & 28.91 & 15.94 & 2.11 & 57.08 & 132.51 & 56.26 & 8.70 & 206.05 \\
$\mathrm{~S}$ & 473.47 & 331.55 & 84.37 & 1076.80 & 607.40 & 375.12 & 14.02 & 1174.16 \\
$\mathrm{Cl}$ & 60.44 & 52.29 & 19.75 & 197.01 & 585.23 & 370.76 & 8.00 & 1071.52 \\
$\mathrm{~K}$ & 182.63 & 113.40 & 20.91 & 380.06 & 285.40 & 134.48 & 8.73 & 465.91 \\
$\mathrm{Ca}$ & 114.37 & 97.00 & 3.98 & 329.46 & 1310.72 & 567.90 & 21.97 & 2215.66 \\
$\mathrm{Ti}$ & 4.65 & 5.37 & 0.42 & 19.25 & 71.78 & 31.69 & 1.46 & 125.90 \\
$\mathrm{Cr}$ & 1.78 & 0.65 & 0.96 & 2.91 & 8.98 & 4.28 & 0.21 & 14.43 \\
$\mathrm{Mn}$ & 3.52 & 1.56 & 1.87 & 5.93 & 20.57 & 8.25 & 0.44 & 29.77 \\
$\mathrm{Fe}$ & 75.45 & 55.90 & 5.58 & 209.66 & 931.22 & 413.61 & 11.90 & 1548.19 \\
$\mathrm{Cu}$ & 1.79 & 1.19 & 0.61 & 4.01 & 11.78 & 6.67 & 1.09 & 23.68 \\
$\mathrm{Zn}$ & 12.48 & 9.07 & 2.21 & 28.58 & 31.46 & 12.26 & 4.69 & 53.55 \\
$\mathrm{As}$ & 2.23 & 1.45 & 1.36 & 4.39 & 7.22 & 3.05 & 4.99 & 14.47 \\
\hline
\end{tabular}




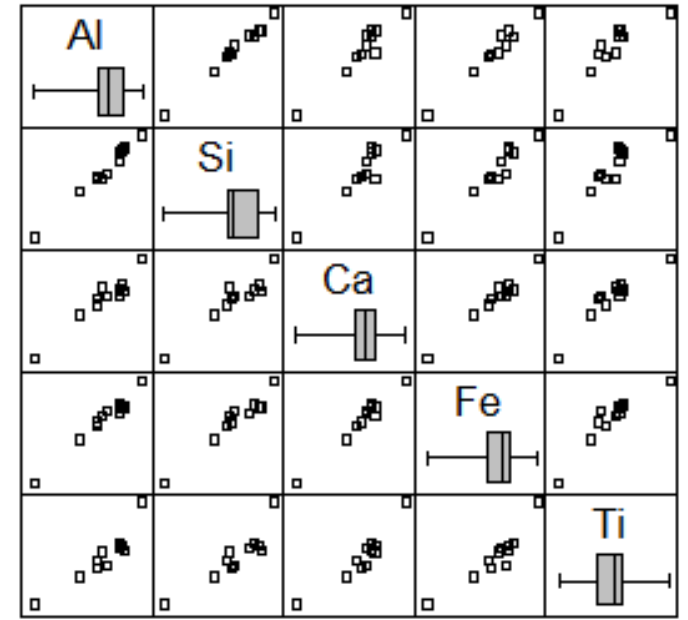

(a) Kiaracondong sites



(b) Holis sites

Fig 3. Correlation plot for the five major soil components for fine fractions

Table 3. Factor analysis with varimax rotation for fine fraction data:

\begin{tabular}{lcccc}
\multicolumn{5}{c}{ a. from Kiaracondong site } \\
\hline Parameter & Factor 1 & Factor 2 & Factor 3 & Factor 4 \\
\hline $\mathrm{BC}$ & -0.6601 & $\mathbf{0 . 5 6 3 7}$ & 0.2031 & 0.0586 \\
$\mathrm{Na}$ & $\mathbf{0 . 8 3 7 4}$ & -0.5036 & -0.0372 & -0.0448 \\
$\mathrm{Al}$ & $\mathbf{0 . 9 7 4 6}$ & 0.0779 & -0.0444 & 0.2423 \\
$\mathrm{Si}$ & $\mathbf{0 . 9 6 3 7}$ & 0.1259 & -0.0902 & 0.2326 \\
$\mathrm{~S}$ & -0.1944 & $\mathbf{0 . 9 2 8 1}$ & 0.0508 & -0.0013 \\
$\mathrm{~K}$ & 0.3200 & $\mathbf{0 . 8 3 6 3}$ & 0.3990 & -0.0124 \\
$\mathrm{Ca}$ & $\mathbf{0 . 9 8 6 3}$ & -0.0369 & -0.0497 & 0.0984 \\
$\mathrm{Ti}$ & $\mathbf{0 . 9 5 5 4}$ & 0.1904 & 0.0401 & -0.0051 \\
$\mathrm{Cr}$ & -0.0244 & -0.0254 & 0.0260 & $\mathbf{0 . 9 7 4 9}$ \\
$\mathrm{Mn}$ & $\mathbf{0 . 8 8 8 1}$ & -0.1147 & 0.3587 & -0.2157 \\
$\mathrm{Fe}$ & $\mathbf{0 . 9 9 2 6}$ & -0.0214 & 0.1550 & 0.2046 \\
$\mathrm{Zn}$ & 0.0640 & $\mathbf{0 . 9 6 4 1}$ & -0.1642 & 0.0043 \\
$\mathrm{Cu}$ & $\mathbf{0 . 3 7 7 7}$ & 0.0352 & $\mathbf{0 . 9 2 3 8}$ & -0.0161 \\
\hline
\end{tabular}

b. from Holis site

\begin{tabular}{lcccc}
\hline Parameter & Factor 1 & Factor 2 & Factor 3 & Factor 4 \\
\hline $\mathrm{BC}$ & 0.6627 & 0.0228 & $\mathbf{0 . 5 1 6 2}$ & 0.4355 \\
$\mathrm{Na}$ & 0.0597 & 0.1090 & 0.0953 & $\mathbf{0 . 9 5 0 3}$ \\
$\mathrm{Al}$ & $\mathbf{0 . 9 2 6 3}$ & -0.1046 & 0.2594 & 0.2012 \\
$\mathrm{Si}$ & $\mathbf{0 . 9 4 3 4}$ & -0.1158 & 0.1900 & 0.2038 \\
$\mathrm{~S}$ & 0.2162 & 0.0768 & $\mathbf{0 . 9 3 3 1}$ & -0.1520 \\
$\mathrm{Cl}$ & 0.4258 & 0.1880 & -0.1084 & $\mathbf{0 . 8 2 5 1}$ \\
$\mathrm{K}$ & 0.2812 & -0.0657 & $\mathbf{0 . 6 2 9 3}$ & 0.6386 \\
$\mathrm{Ca}$ & $\mathbf{0 . 9 5 5 9}$ & -0.0365 & 0.1540 & 0.1437 \\
$\mathrm{Ti}$ & -0.1073 & $\mathbf{0 . 8 9 6 5}$ & 0.0788 & 0.0286 \\
$\mathrm{Cr}$ & -0.1809 & $\mathbf{0 . 9 2 8 9}$ & 0.0642 & -0.1083 \\
$\mathrm{Mn}$ & 0.1113 & $\mathbf{0 . 8 2 0 0}$ & -0.2565 & 0.3947 \\
$\mathrm{Fe}$ & $\mathbf{0 . 8 9 4 0}$ & -0.0714 & 0.3738 & 0.2061 \\
$\mathrm{Zn}$ & 0.3737 & -0.0644 & $\mathbf{0 . 8 7 7 2}$ & 0.1058 \\
\hline
\end{tabular}

sampling sites ranged from 13-31\%. These values do not differ significantly with the values reported in industrial area in Serpong area in 2008 (13-26\%) which used the same sampling method and analytical procedure [13]. Transport related emissions are the major source of BC and long-range transport from fossil fuel related sources and biomass burning could be other substantial sources of BC [14].

\section{Elemental Concentrations}

Several elements were detected by PIXE in fine and coarse fractions. Elements such as $\mathrm{Na}, \mathrm{Mg}, \mathrm{Al}, \mathrm{Si}$, $\mathrm{P}, \mathrm{S}, \mathrm{Cl}, \mathrm{K}, \mathrm{Ca}, \mathrm{Ti}, \mathrm{Mn}, \mathrm{Fe}$ and $\mathrm{Zn}$ were detected in the most of the filters (over $90 \%$ ), $\mathrm{Cu}$ and As were present in more than $30 \%$ of the samples, while $\mathrm{V}, \mathrm{Br}, \mathrm{Hg}$ and $\mathrm{Pb}$ were detected in less than $10 \%$ of the samples. The average elemental concentrations in coarse and fine particulate matter in Kiaracondong and Holis sampling sites are shown in Table 2.

High concentration of $\mathrm{Al}, \mathrm{Si}, \mathrm{Ca}, \mathrm{Fe}$ and $\mathrm{Mn}$ which are crustal elements, $\mathrm{S}$ and $\mathrm{Zn}$ were identified in $\mathrm{PM}_{2.5}$ and $\mathrm{PM}_{10}$ for both sites.

Fig. 3 shows the multiple correlation plot for the five major soil component of $\mathrm{Al}, \mathrm{Si}, \mathrm{Ca}, \mathrm{Fe}$ and $\mathrm{Ti}$ for each site. This matrix plot produced using software Statgraphics Plus ${ }^{\circledR}$ consists of all pair wise scatter plots of the variables, including all of their respective transposed plots. The first row of the matrix contains plots of the first variable specified on the data input dialog box on the $Y$ axis versus each of the other variables on the $X$ axis. The first column of the matrix contains plots of the first variable on the $X$ axis versus each of the other variables on the $Y$ axis. The main diagonal shows Box-and-Whisker plots for each of the variables. For Kiaracondong site, it shows good linear correlations for all elements while for Holis site there were good correlations between $\mathrm{Al}, \mathrm{Si}, \mathrm{Ca}$ and $\mathrm{Fe}$, but not with $\mathrm{Ti}$. Element associated with $\mathrm{Ti}$ is suggested from other source at least this site has more than one source of Ti besides soil component. 
Sulphur in airborne particulate matter is generally present because of the atmospheric conversion of $\mathrm{SO}_{2}$ to sulfate through homogenous processes [15]. Thus in general, only a portion of the particulate sulfate is the result of local sources because there is insufficient time to allow substantial conversion. Zinc is emitted from municipal solid waste, galvanizing operations, and nonferrous metal smelting. All of these sources contribute to the fine fraction. However, the two stroke engine emissions can provide substantial zinc contribution to the urban street dust and thus also be found in coarse fraction [15].

\section{Principal Component Analysis}

The trends in data monitored were analyzed using an approach based on factor analysis to identify quantitatively the source contributing to the pollution. To address the air quality issues, it is always necessary to have information on possible source contribution. A multivariate principal component analysis using Statgraphics Software was applied to the fine fraction data set to identify the major elements associated with the sources. Factors with two or more elements having factor loadings above 0.5 have been highlighted. The varimax factor loadings after rotation are presented in Table 3. The loadings are showing the value of a correlation coefficient between the original variables and new factor variables that represent a linear combination. Loading values over 0.50 are generally significant provide insights into the nature of the sources [11].

\section{Kiaracondong sampling site}

Factor analysis for data from Kiaracondong site was identified four factors. The identified sources are attributed to soil, biomass burning and vehicle emissions, non ferrous smelter and iron/steel work industry. The first factor is crustal elements $\mathrm{Al}, \mathrm{Si}, \mathrm{Ca}, \mathrm{Fe}$ and $\mathrm{Ti}$ which are recognized as typical soil indicators. It also can be seen from the correlation among these elements that it has strong correlation for each element. There is additional loading from $\mathrm{Na}$ which indicates that soil factor is also mixed with sea-salt. The second factor has the characteristic of high BC, S, K and $\mathrm{Zn}$. This combination of elements suggests the contribution from biomass burning which is indicated by potassium that is strongly related to the biomass combustion, and vehicular emissions indicated from high $S$ and $Z n$ [13]. Bandung still has a large area of rice fields which is the main source of biomass burning and open solid waste burning from residential activity is also a potential source of biomass burning [7]. High concentration of $S$ is attributed to the low fuel quality. Sulfur comes from diesel vehicles emissions since Indonesia still has high sulfur content in diesel fuel [5]. There is a fly-over road about $500 \mathrm{~m}$ to the west side of the sampling site, with many heavy vehicles pass through this area. The third factor is related to $\mathrm{Cu}$ from non ferrous smelter. In this sampling site, there is one big scale metal workshop industry which estimates to contribute to this factor. This industry also contributes to the fourth factor that has high factor loading for $\mathrm{Cr}$. This element would be expected to be related to the iron/steel works [11]. It is more logical if $\mathrm{Fe}$ also has high positive loading on this factor, but due to the limited numbers of data the clearly correlation was not obtained.

\section{Holis sampling site}

Factor analysis for data from Holis site was identified four factors. The first factor is crustal elements represent soil component. The second factor has high loading for $\mathrm{Ti}, \mathrm{Cr}$ and $\mathrm{Mn}$ which indicated as the fingerprint of industrial activities. $\mathrm{Ti}$ could be expected from paint pigment plant that produces $\mathrm{TiO}_{2}$ and is a major source of fine particle titanium. In this sampling site, there are several painting textile industries which may contribute to this source. This $\mathrm{Ti}$ source was clearly showed up when plotting the correlation of crustal elements for soil component (Fig. 3 (b)). It shows that apparently there is another $\mathrm{Ti}$ source, since $\mathrm{Ti}$ appears having a negative correlation with the other crustal elements. The third factor is related to $\mathrm{BC}, \mathrm{S}, \mathrm{K}$ and $\mathrm{Zn}$. This factor would be expected from vehicular emission especially from diesel vehicles mixed with biomass burning which also emits large quantity of black smoke. The fourth factor is clearly sea-salt by the presence of $\mathrm{Na}$ and $\mathrm{Cl}$ correlation. It appears to be quite number of loading for $\mathrm{BC}$ and $\mathrm{K}$ which indicates that biomass burning could be mixed with this factor.

\section{CONCLUSION}

The airborne particulate samples collected from two semi industrial sites Kiaracondong and Holis in Bandung, Indonesia were characterized using particles induced $\mathrm{x}$-ray emission to investigate the sources of pollution, as a preliminary study in step to the evaluation of air quality in these areas. Concentrations of crustal elements, $S$ and $\mathrm{Zn}$ were found in high levels for both sites. A multivariate approach of principal component analysis has revealed four factors in each site. For Kiaracondong site, identified factors are attributed to sea-salt with soil dust, vehicular emissions and biomass burning, non ferrous smelter, and iron/steel work industry, while for Holis site identified factors are attributed to soil dust, industrial emissions, vehicular emissions with biomass burning, and seasalt. Although particulate samples were collected from semi industrial areas, vehicular emissions especially 
diesel vehicles constituted with $\mathrm{S}, \mathrm{Zn}$ and $\mathrm{BC}$ were identified in both sites. Different sources such as non ferrous smelter and iron/steel work industry sources have also been identified in Kiaracondong due to sampling site characteristic which closed to the big scale metal industry.

\section{REFERENCES}

1. Pope, C.A., Burnett, R.T., Thurston, G.D., Thun, M.J., Calle, E.E., Krewski, D., and Godleski, J.J., 2004, Circulation, 109, 1, 71-77.

2. Katsouyanni, K., 2005, Occup. Environ. Med., 62, 7, 432-433.

3. Duki, M.I., Sudarmadi, S., Suzuki, S., Kawada, T., and Tri-Tugaswati, A., 2003, Arch. Environ. Health, 58, 3, 135-143.

4. Clean Air Initiative for Asian Cities (CAl-Asia) Center, 2010, Indonesia: Air Quality Profile 2010 Edition.

5. Santoso, M., Hopke, P.K., Hidayat, A., and Lestiani, D.D., 2008, Sci. Total Environ., 397, 1-3, 229-237.

6. Statistics Indonesia, 2010, Population census 2010 Province Jawa http://www.bps.go.id/aboutus.php?sp=0\&kota $=32$

7. Lestari, P., and Mauliadi, Y.D., 2009, Atmos. Environ., 43, 10, 1760-1770.

8. Hopke, P.K., Xie, Y., Raunemaa, T., Biegalski, S., Landsberger, S., Maenhaut, W., Artaxo, P., and
Cohen, D.D., 1997, Aerosol Sci. Technol., 27, 6, 726-735.

9. Campbell, J.L., Boyd, N.I., Grassi, N., Bonnick, P., and Maxwell, J.A., 2010, Nucl. Instrum. Methods Phys. Res., Sect. B, 268, 20, 3356-3363.

10. Cohen, D.D., Garton, D., Stelcer, E., and Hawas, O., 2004, Radiat. Phys. Chem., 71, 3-4, 759-767.

11. Hopke, P.K.,1999, An Introduction to Source Receptor Modeling, in Elemental Analysis of Airborne Particles, Landsberger, $S$ and Creatchman M eds., Gordon and Breach Science Publishers, Amsterdam, pp. 273-315.

12. Government Regulation, National ambient air quality standard, PP no.41/1999.

13. Santoso, M., Lestiani, D.D., Mukhtar, R.,Hamonangan, E., H., Syafrul, H., Markwitz, A., and Hopke, P.K., 2011, Atmos. Pollut. Res., 2, 190-196.

14. Begum, B.A, Tazmin, A., Rabbani, K.A., Biswas, S.K., and Nasiruddin, M., 2009, J. Bangladesh Acad. Sci., 33, 1, 71-85

15. Hopke, P.K., Cohen, D.D., Begum, B.A., Biswas, S.K., Ni, B., Pandit, G.G., Santoso, M., Chung, YS., Davy, P., Markwitz, A., Waheed, S., Siddique, N., Santos, F.L., Pabroa, P.C.B., Seneviratne, M.C.S., Wimolwattanapun, W., Bunprapob, S., Vuong, T.B., Hien, P.D., and Markowicz, A., 2008, Sci. Total Environ., 404, 1, 103-112. 